\title{
EMEVILER VE ABBASILER DÖNEMINDE SURiYe-Fílistin'in DoĞU AKDENiz KIYILARINDA Gemi Tersaneleri Ve Deniz HaREKÂT ÜSLERI
}

\author{
Mustafa Zeki TERZI $\dot{I}^{*}$
}

\begin{abstract}
Öz
Araştırmamızın konusu; Fmeviler ve Abhasiler Dönemi'nde Suriye-Filistin'in Doğu Akdeniz kıyılarında inşa ve tesis edilen tersaneler ve deniz harekât üsleridir. Bu konuda Türkiye'de yayımlanmış bir araştırma ve makaleye rastlayamadık. Konuyu daha geniş bir çalışma içerisinde bütün boyutlarıyla araştırdık. Bu makale o araștırmamızın bir bölümünü oluşturmaktadır. Makalemiz Giriş, Akkâ Deniz Üssü ve Tersanesi, Saydâ ve Sûr Deniz Üsleri ve Tersaneleri, Tarsus Deniz Üssü ve Tersanesi, Sonuç ve Kaynakça'dan oluşmaktadır. Emevi ve Abbasi dönemlerinde İslâm coğrafyasının üç bir tarafı denizlerle çevrili olup öteden beri Bizans ve Hind donanmaları bu denizlerde egemendir. Bu yüzden İslâm toprakları denizden vaki düşman donamalarının saldırılarına her zaman açık haldedir. Bu durum Müslüman devlet yöneticilerini İslâm donanması/deniz gücü hazırlamaya sevk etmiştir. Neticede bu kıyılarda fetih öncesi de var olan tersaneler ve havuzlar yeniden onarılmış, bu tersanelerde, daha önce mevcut usta ve sanatkârlardan da yararlanılarak yeni savaş gemileri inşa edilmiştir. Tersanelerin yer aldığı bu limanlar, askeri yapılanma çerçevesinde yeniden donatılarak bahriye/donanma kuvveti ve deniz harekât üsleri kurulmuştur. Araştırmamız literatür taramasına dayanmaktadır.
\end{abstract}

Anahtar kelimeler: Suriye-Filistin, Tersane, Gemi, Deniz Harekât Üsleri, Donanma, Akkâ, Sûr, Saydâ, Tarsûs.

\section{SHIPYARDS AND NAVAL OPERATIONS BASES BUILT AND INSTALLED ON THE EASTERN MEDITERRANEAN COASTS OF SYRIA-PALESTINE IN THE TIME OF UMAYYADS AND ABBASIDS}

\begin{abstract}
In this article, the subject of "Shipyards and naval operations bases built and installed on the Eastern Mediterranean coasts of Syria-Palestine during the Umayyads and Abbasids" is discussed. The aim of the research is to reveal the importance and importance of the shipyards and naval operations bases built and installed on the East Mediterranean coasts of Syria-Palestine during the Umayyad and Abbasid period. The fact that no research has been done in our country on this subject gives the study a unique quality. Our research is based on the literature review and the subject of the article is examined in all aspects. Our study consists of subtitles of Akkâ Naval Base and Shipyard, Tarsus Naval Base and Shipyard, Saydâ and Sûr Naval Bases and Shipyards. It is known that all three sides of the Islamic world were surrounded by the seas during the Umayyad and Abbasid periods. Byzantine and Hind navies have dominated these seas ever since. Therefore, Islamic lands are open to enemy navy attacks that may come from the sea. This situation has prompted Muslim
\end{abstract}

* Prof. Dr., Emekli Öğretim Üyesi, ORCID ID: 0000-0003-2944-2411, e-mail: mustafazekiterzi@gmail.com 
state administrators to prepare Islamic navy / naval power. In this context, the shipyards and pools that existed on the coasts before conquest were repaired, and new warships were built in these shipyards by making use of the existing masters and craftsmen. These ports, where the shipyards are located, have been re-equipped in the concept of military structuring and naval and naval operations bases have been established.

Keywords: Syria-Palestine, Shipyard, Naval Operations Bases, Akkâ, Sûr, Saydâ, Tarsûs.

Makalenin Geliș Tarihi: 26.08.2020; Makalenin Kabul Tarihi : 15.11.2020

\section{Giriş}

Hz. Peygamber (as) zamanında Müslüman orduların katıldığı teşkilâtlı ve donanımlı bir deniz savaşı harekâtı vuku bulmamıştır. Ancak bu dönemde denize yönelik bir sefer olarak niteleyebileceğimiz ilk deniz harekâtı, 9/630 yılında Mekke'nin sahildeki limanı Şuaybe açıklarında, gemilere binmiş zenci korsanların görülmesi üzerine, Hz. Peygamber'in (as) onlara karşı, 300 kişilik bir kuvvetin başında, Alkame b. Mücezziz el-Müdlicîyi, göndermesi ile başlar. Kıyıya yakın bir adaya çıkarma yapan bu deniz kuvveti karşısında zenci korsanlar çekilmek zorunda kalmışlardır. Aynı Alkame'nin, bu defa 20/641 yilında, Hz. Ömer (13-23/634-644) tarafindan deniz yoluyla Habeşistan'a gönderildiğini görmekteyiz. ${ }^{1}$

Denizle ilgili bu durum Hz. Ebu Bekir (11-13/632-634) ve Hz. Ömer zamanlarında aynen devam etti. İlk Müslüman Araplar çölde bedevi, şehirde hadâri bir hayat sürdükleri için denize karşı ilgisiz kalıyorlar ve hatta belki de denizden korkuyorlardı. Bu yüzden çöl gemisi diyebileceğimiz deveyi deniz gemisine tercih ediyorlardı.

Hz. Ömer Dönemi'nde gerçekleştirilen fetihler sonucunda, Müslümanların Doğu Akdeniz sahillerinin büyük bir kısmını ele geçirmelerinin ve bu bölgelerin denizden gelebilecek tehlikelere açık bulunmasının, onları bir bahriye/deniz gücü hazırlama konusunda ciddi şekilde düşünmeye yönelttiği görülür. Ayrıca bu sırada Şâm/Suriye-Filistîn ve Mısır'ın servetinin büyük bir kısmının ticarete dayanıyor olması ve I.Justinianos devrinden (M.S.527-565) beri Akdeniz'deki ticaretin Şâm/Suriye-Filistînli ve Mısırlı tacirlerin elinde olması, bu iki yerin valilerinin, bölgenin askeri bakımdan korunması ve Akdeniz ticaretinin devam ettirilmesi için bir İslâm donanması oluşturmanın önemini çabucak kavramalarına sebep oldu. Müslümanlar böyle bir donanmayı oluşturacak imkânlara da esasen sahiptiler. Çünkü Mısır ve Suriye-Filistin'nin Doğu Akdeniz sahillerindeki tersanelerini ele geçirmişlerdi. Eskiden beri burada denizci

1 Hamidullah, İslam Peygamberi, çev. Salih Tŭg (İstanbul: İrfan Yayınevi, 1980), 1/271; A.mlf., Hz. Peygamber'in Savaşları (Ankara, ts.), 131. 
bir halk zaten vardı ve bu yüzden gerekli usta/sanatkâr personel kolaylıkla sağlanabilirdi. Önceleri denizciliğe kuşku ile bakan Müslümanlar çok geçmeden gözlerini denize çevirdiler ve Bizans'ın denizdeki üstünlüğü devam ettiği sürece Mısır ve Şâm/Suriye-Filistin'deki hâkimiyetlerinin tehdit altında olduğunu anladılar. ${ }^{2}$

24/645 senesinde Bizanslılar'ın bir çıkarma harekâtı sonunda İskenderiye'yi ele geçirmeleri üzerine Bizans'a karşı mücadelenin, donanmanın desteğini almadan yürütülemeyeceğini fark eden ilk devlet adamı Muâviye b. Ebû Süfyân (ö.60/680) olmuștur. Şâm/Suriye valisi iken Hz. Ömer'e yazdığı, sahillerin durumunu anlatan ve denize açılma izni isteyen yazısından, kendisinin böyle bir deniz seferi için hazırlık içinde bulunduğunu anlamaktayız. Ancak ne var ki, Hz. Ömer Müslümanların henüz denize açılabilecek bilgi ve tecrübeye sahip olmadığı kanaatindeydi. Bu maksatla Mısır valisi Amr b. Âs'a (ö.43/664) gönderdiği bir yazı ile ondan deniz ve tehlikeleri hakkında bilgi istedi. Vali Amr'ın Halife'ye gönderdiği cevabi yazıda; denizin tehlikelerinden bahsetmesi sebebiyle, hiçbir Müslüman'ın böyle bir tehlikeye atılmasına izin vermeyeceğini Muâviye'ye bildiren Hz. Ömer, ondan; a)kaleleri onarmasını ve buralara asker yerleștirmesini, b)gözetleme kuleleri inşa ettirip buralara nöbetçiler koydurmasını ve c)geceleri buraların fenerlerle aydınlatılmasını istemiş; Amr'a da, "Müslümanların deniz savaşlarından uzak tutulmasını" yazılı bir emir ve talimatla bildirmiştir. ${ }^{3}$

Halife Ömer'in, bir deniz seferi esnasında doğrudan denizden gelecek tehlikeler hakkında, bu işi bilenlerden bilgi ve görüş almasının yanında, yukarıda kaydettiğimiz; Alkame b.Mücezziz'in bu yolculuk esnasında çıkan firtınaya yakalanıp askerleri ile birlikte boğulmasının da etkisiyle artık bundan sonra, çıkılması teklif edilen deniz harekâtına karşı kuşku ile baktığı ve bu yüzden kumandanlarına deniz seferlerini yasakladığı görülür. O 'nun denizi; kendisi ile düşmanları arasında tabiî bir koruma, bir engel ve bir kale olarak değerlendirdiğini görmekteyiz. O aynı zamanda kendisi ile askerleri arasında bir su engelinin olmasını $d a$ istemiyordu. Hz. Ömer'in şu sözü onun bu konuda ne ölçüde hassas olduğunu göstermektedir: "Müslümanlardan bir kişiyi küffar elinden kurtarmam benim için Cezîretü'l-Arab'tan daha değerlidir." ${ }^{4}$ Onun; deniz seferlerinde yeterli ölçüde bir tecrübeye henüz sahip olmayan askerlerini, ortaya çıkabilecek tehlikelere karșı koruma endișesiyle böyle bir strateji takip ettiğini söyleyebiliriz.

Şam/Sûriye-Filistîn valisi Muâviye b. Ebû Süfyân'ın bir deniz seferi için bu defa dönemin İslâm Devlet Başkanı/Halîfe Hz. Osman'a (23-35/644656) başvurduğunu görmekteyiz. Hz. Osman'ın halifeliğinin ilk yıllarında

2 Terzi, Hz. Peygamber ve Hulefâ-yi Râş̧idîn Döneminde Askeri Teşkilât (İstanbul: Siyer Yaymları, 2017), 198-199.

3 Bozkurt, "Bahriye", TDV İslâm Ansiklopedisi (İstanbul, 2009), 4/496.

4 Ya'kub b. İbrâhim Ebû Yûsuf, Kitâbü'l-Harâc, thk. Muhibbüddin el-Hatib (Kahire: elMatbaatü's-Selefiyye, 1936), 212. 
Muâviye, deniz seferleriyle ilgili isteklerini $\mathrm{Hz}$. Ömer gibi cevaplayan $\mathrm{Hz}$. Osman'ı sonunda bir deniz harekâtına ikna etmiş, Halîfe de; sahillerin askeri birliklerle takviye edilmesi ve bu maksatla teşkil edilecek olan deniz ordusu birliklerine alınması düşünülen askerlerin; zorla değil de gönüllü olarak katılmaları ve vali Muâviye'nin, yanına hanımını da alması şartıyla ancak buna izin vermiştir. ${ }^{5}$

Hz. Osman döneminde, bilhassa sahillerin düşman saldırısına karşı korunması amacıyla bir dizi askeri tedbir alındığını görmekteyiz. Bunlar arasinda;

a) Kalelerin onarılmasinı,

b) Kalelere savas erleri yerlestirilmesini,

c) Kulelere muhâfızlar/bekçiler/gözetleyiciler ve fenerler yerleştirilmesini,

d) Sahillere daha önce yerleştirilen birliklere ilave olarak yeni birlikler getirilmek suretiyle kıyı savunma ve koruma kuvvetinin artırılmasını,

e) Önceki sakinleri tarafindan terk edilen binaların askerî amaçlarla kullanilmasini,

f) Mescidler yapılmasını ve daha önce yapılmış olan mescidlerin onarılmasını sayabiliriz. ${ }^{6}$

Böylece Bizans Donanması'nın saldırılarına, mukabele etme/karşı koyma harekâtı imkânı bulan İslâm Deniz Gücü, Kıbrıs adasına karşı ilk deniz harekâtına çıktı. Muâviye Mısır valisi Abdullah b. Sa'd b. Ebû Serh'i (ö.36/656657) de bu harekâta çağırdı. Müslüman Deniz Filosu 28/649 yılının ilkbaharında 1.700 parça gemiyle Akkâ'dan denize açıldı. Muaviye bu donanmanın idaresini Abdullah b. Sa'd b. Ebû Serh ile Abdullah b. Kays'a verdi. Kıbrıs adasına yönelik bu deniz seferine sahabeden birçok gönüllünün yanında Ubâde b. Sâmit (ö.34/654) ile Hz. Peygamber'in teyzesi olan hanımı Ümmü Harâm (ö.28/648) da katıldı Müslüman deniz gücü askerleri Kıbrıs'ın merkezi Konstantia önünde karaya çıkarak şehri kuşattılar. Karaya çıkıldığı sırada Ümmü Harâm bindiği hayvandan düşerek öldü. "Hala Sultan Tekkesi” adıyla anılan türbesi bugün de ziyaret edilmektedir. Kuşatma sonunda Kıbrıs adası barış antlaşması akdedilerek ele geçirildi. Antlaşma 7.200 altın vergi ödenmesi ve Müslümanlar'a saldırılmaması şartlarını taşıyordu. Kıbrıslılar birkaç yıl antlaşma şartlarına uydular. Deniz yoluyla İstanbul'a ulaşmayı hedefleyen Muâviye bu süre içinde donanmasını güçlendirdi. 33/654 yılında Kıbrıs üzerine yapılan ikinci seferde ada yeniden fethedilmiş ve buraya 12.000 kişilik bir

5 Ebü'l-Abbas Ahmed b. Yahyâ b. Câbir el-Belâzürî, Fütûhü'l-büldân (Beyrut: Dârü'lKütübi'l-İlmiyye, 1978), 157.

6 Belâzürî, Fütûhü'l-büldân, 183; Ebü'l-Hasan İzzeddin Ali b. Muhammed b. Abdülkerim İbnü'l-Esîr, el-Kâmil fi't-târîh, thk. Johannes Tornberg (Beyrut, 1965), 2/495. 
askeri kuvvet yerleştirilmiştir. ${ }^{7}$ Bu yerleşmeden sonra da adada tam anlamıyla bir Müslüman hâkimiyetinden bahsedilemez. Fakat Müslüman ülkeleri için Kıbrıs artık bir tehlike olmaktan çıkmıştır.

Kıbrıs adasının alınması ve Anadolu içlerine yapılan birkaç seferden sonra Muâviye Bizans'a karşı dış politika stratejisini Bizans'ın payitahtını hedef olarak belirlemiştir. Kıbrıs'ın fethinden iki yıl sonra 34/654-655 yılında Müslümanlar ile Bizanslılar arasında ilk deniz savaşı vuku bulmuştur. Muâviye'nin İstanbul'u karadan ve denizden kuşatmak için yoğun bir şekilde Suriye-Filistin, Mısır ve İfrîkıyye/Kuzey Afrika sahillerinde gemi inşaatına ağırlık verdiğini görmekteyiz. Bu maksatla daha önceden de yapıldığı gibi Finike sahillerinden gemi inşaat malzemesi olarak ahşap ticareti sürdürülmüş ve önemli ölçüde bir donanma gücü oluşturulmuştur. Bu deniz gücünün oluşturulmasında Mısır Valisi Abdullah b. Sa'b b. Ebû Serh ile de iş birliği yapılmış ve kısa zamanda Ískenderiye tersanesinde çok sayıda savaş gemisi inşa edilmiştir. Bu hazırlıkların ardından kendisi de Kapadokya üzerinden kara ordusuyla sefere harekâtı düzenlemiştir. Öbür taraftan onun hedefini anlayan İmparator Herakleios'un (M.S.610-641) torunu II. Konstans (II.Konstantin) (M.S.641-668) karşı saldırıya geçmiş ve denizden sefere çıkarak Likya açıklarında İslâm Donanması'yla karşılaşmıştır. Denizde gelișen bu ilerleyiş Doğu Akdeniz'de, biri Şam Valisi Muâviye'nin komutasında Sûriye-Filistin Donanması'nın, diğeri Abdullâh b. Sa'd b. Ebû Serh komutasındaki Mısır Donanması'nın birleşmesiyle 200 parça gemiden oluşan iki Müslüman deniz gücünün II. Konstans komutasındaki 500 parça gemiden oluşan Bizans Donanması'na karşı Likya bölgesinde yer alan Phoenix (günümüzde Finike ve Antalya) açıklarında ünlü Zâtü's-Savârî (Gemi Direkleri) Savaşı'nın (34/655) kazanılmasını sağlamıştır. İslâm Donanması'nın ekseriyetini Abdullah b. Sa'd b. Ebû Serh'in komuta ettiği Mısır Donanması oluşturuyordu. Bizans Donanması'nın üstün donanıma sahip olmasına rağmen Müslüman askerler, düşman gemilerinin donanımını imha etmek ve yelkenlerini kesmek için uzun kancalar kullanmışlar, kendi gemileri ile Bizans gemilerini halat ve zincirlerle birbirine bağlayarak hücuma geçmişler ve böylece alışkın olmadıkları deniz savaşını adeta kara savaşı haline dönüştürerek göğüs göğüse çarpışmaya girişmişlerdir. Savaş Müslüman deniz gücünün kesin zaferiyle sona ermiștir. Böylece güçlü Bizans Donanması Likya (Günümüz Akdeniz Bölgesi) sahillerinde ağır bir yenilgiye uğramış ve İmparator ancak kılık değiştirerek savaştan kaçmayı başarabilmiştir. Bu başarılarından sonra Müslümanlar denizlerde de Bizans'a karşı üstünlüklerini artırarak sürdürmüşlerdir. Finike (Alanya-Antalya) yakınlarında/açıklarında gerçekleşen Zâtü’s-Savârî savaşıyla birlikte Bizans'ın Doğu Akdeniz'deki tek ve rakipssiz vurucu ve kuşatıcı hâkimiyetinin sona erdiğini görmekteyiz.

7 Belâzürî, Fütûhü'l-büldân, 157-158; Ebü'l-Ferec Barhebraeus Yuhanna İbnü'l-İbrî, $A b u$ 'lFarac Tarihi, çev. Ömer Rıza Doğrul (Ankara: Türk Tarih Kurumu, 1999), 1/180-182; Halîfe b. Hayyât, Târîhu Halîfe b. Hayyât (Riyad, 1985), 160; Halîfe b. Hayyât, Târîhu Halîfe b. Hayyât, çev. Abdülhalik Bakır (Ankara: Bizim Büro Basımevi, 2001), 62-63, 67-70. 
İslâm donanmasının denizdeki bu seferleri ve bunlardaki başarısı Müslümanları müteakip yıllarda, diğer Akdeniz adalarına karşı yeni seferler tertip etmeye cesaretlendirmiş; İslâm ordularının, denize de hâkim olup onu kontrolleri altına almalarının yolunu Müslümanlara açmış ve İslâm deniz gücünün Akdeniz'deki varlı̆̆ı ve hâkimiyetinin kabulü sonucunu doğurmuştur. Bu sonuç Bizans'a, Akdeniz'deki gücünü yeniden takviye ihtiyacını duydurtmuştur. Bundan sonraki süreç İstanbul'u kuşatma girişimi ile neticelenmiştir.8

Muâviye'nin kurduğu 1.700 gemilik Suriye-Filistin Donanması ve bir o kadar da Mısır Donanması ile "íslâm Deniz Harp Filosunun" Akdeniz'de önemli bir güce ulaştığı görülür. Bu gücün etkisi iledir ki İslâm Donanması'nın; Akdeniz havzasında yer alan Kıbrıs, Arvad, ${ }^{9}$ Sicilya, Rodos ve Girit gibi önemli deniz üslerini ele geçirmek için Bizans Donanması'nı sıkıştırdığını görmekteyiz. Bu üsler ileride İstanbul'a yönelik "Yedi Sene Savaşları (53-60/674680)" adı verilen askerî seferler için "İslâm Deniz Hareket Üssü" görevi göreceklerdir. ${ }^{10}$

Karada ve denizde İslâm hâkimiyetinin yayılması, mağlup milletlerdeki çeşitli mesleklerde maharet ve beceri elde etmiş tecrübeli sanatkâr ustaları Íslâm'a yaklaştırdı. Bundan sonra bu ustalar kendi meslek ve sanat alanlarında İslâm devlet[ler]inin hizmetinde istihdam edildiler. Bu vesileyle gemi yapımında da, bu alanda tecrübe sahibi mahir ve sanatkâr ustalardan, özellikle Rûm/Romalı/Bizanslı ustalardan önemli ölçüde yararlanıldı. İslâm denizciliği, daha Muâviye b. Ebû Süfyân'ın Şam/Suriye-Filistîn valiliği sırasında, ele geçirilen sahillerdeki gemi tezgâhları/gemi yapım atölyeleri ve İskenderiye'deki tersanenin Islahı ile başladı. ${ }^{11}$

Müslümanlar gemi yapılan yerlere dâru sınâati'l-bahr/dâru's-sınâa adını verdiler. Müslümanlar tarafından ilk tersanelerin kurulduğu dönemde, sanayinin ağırlık merkezini gemicilik san'atı oluşturduğu için, tersaneye; günümüzde sanayi sitesi anlamına gelen dâru's-sınâa adı verilmişti. Batı dillerinde tersane karşıllğında kullanılan "arsenal, arsenale, arzenale, tarzna, darsena, darsanale" gibi kelimelerin de Arapça dâru's-sınâa terkibinden intikal ettiği/geçtiği bilin-

8 Terzi, Hz. Peygamber ve Hulefâ-yi Râşidîn Döneminde Askeri Teşkilât, 204.

9 Burada hemen, isim benzerliğinin sebep olduğu bir yanlıș anlașılmaya işaret etmeliyiz ki, o da şudur: Bazı ansiklopedi maddelerinde (Meselâ, TDV İslâm Ansiklopedisi, "Bahriye" maddesi.), Doğu Akdeniz'deki Arvâd (Ruâd, Arados) Adası ile Marmara Denizi'ndeki Arvâd/Arvat (Kyzikos,Cyzikus/Mysia)Kapıdağ Yarımadası'nın birbirine karıștırıldı̆̆ını görmekteyiz. Aslında bunlar, iki ayrı denizde bulunana iki ayrı adalardır. Muâviye Şâm/ Suriye valisi iken Kıbrıs adasına karşı düzenlediği deniz harekâtından döndükten sonra, Suriye/Filistîn sahilinde, klyı çizgisine iki kilometre uzakta küçük bir ada olan Arvâd (Ruâd, Arados) Adası'na yöneldi ve 29/649 yılında bu adayı fethetti. Burası Doğu Akdeniz'de özel mevkiini koruyan gelişmiş bir ticari limandı. Bkz. Fehmi, "el-Bayriyyetü'l-İslâmiyye fî şarkı'l-bahri'l-mütevassıt mine'l-karni's-sâbi' ile'l-âşiri'l-mîlâdî”, Târîhu'l-Bahriyyeti'lMisriyye (İskenderiye: Camiatü'l-İskenderiye, 1973), 285-286.

10 Belâzürî, Fütûhü'l-büldân, 237; Abdülaziz Sâlim, el-Bahriyyetü'l-İslâmiyye fî Misr ve'ş-Şâm mine'l-Fethi'l-Arabî hattâ'l-Asri'l-Eyyûbî (Beyrut: Dârü'n-Nahdati'l-Arabiyye, 1981), 14-28, 31.

11 Fehmi, Târîhu'l-Bahriyyeti'l-Misriyye, 356-357. 
mektedir. Aynı terkipten gelen tersane tabiri ise Türkçe’ye İtalyanca yoluyla girmiş olmalıdır. Nitekim donanma kumandanı karşılığında kullanılan "emîrü'l-mâ"“ tamlaması da Avrupa dillerine amiral şeklinde geçmiştir. ${ }^{12}$

Birkaç iç denize ve gemilerin çalışmasına müsait nehirlere sahip olan İslâm âleminde çok sayıda tersane yapıldı. Basra körfezinde Übülle, Sîrâf; İfrîkıyye'de Tunus, Trablûs; İspanya'da Issbiliyye, Dania; Fas'ta, Sûs; Sicilya'da Palermo, Messina; Suriye-Filistin'de Akkâ, Sûr, Beyrût, Tarsûs; Mısır'da, Ravza, Fustât (Dârü's-Sinâati Mısr veya Amâir), Maks, İskenderiye ve Dimyât bunlardan bazılarıdır. Makdisî bunlar arasında Gazze, Askalân, Yâfầ ve Ersûfu da zikretmekte ve şöyle demektedir: "Askalân limanı fakir ve sönük, fakat Yafa limanı gayet iyi ve parlaktı."13

Arap-İslâm coğrafyacılarının verdikleri bilgilere göre; Yafa, Filistin ve Remle aynı zamanda ticaret limanı, ${ }^{14}$ Beyrût ise Dımeşk'in limanı idi. Bu limanın, korsan gemilerinin girip de limanı yağmalamalarını önlemek için, Sûr'da olduğu gibi; girişi boyunca çekilip kapatılan ve açllan bir zinciri vardı. ${ }^{15}$ Yâkût, buranın ünlü bir şehir olduğunu, kaydetmektedir. ${ }^{16}$ Ya'kûbî, Trablûs'un bin kadar gemiyi alabilecek çok büyük ve güzel bir limanı olduğunu, kaydetmektedir. ${ }^{17}$ İbn Havkal, insanların Dımaşk'tan ve diğer yerlerden buraya geldiklerini, buranın askeri harekât için bir buluşma ve kavşak noktası olduğunu, kaydetmektedir. ${ }^{18}$

Nâsırî Husrev de; Trablûs'un çok parlak bir șehir olduğunu söylemekte ve bu konuda şunları kaydetmektedir:

“Burası üç taraftan denizden faydalanan bir liman şehridir. Doğu tarafi bir surla/duvarla çevrili olup duvarların üstünde şehri savunmaya yönelik savaş donanımları bulunmaktadır. Çünkü burada yaşayan insanlar Bizans saldırılarından korkmaktadırlar." 19

Aşağıda önemli gördüğümüz ana merkezlerinden birkaçını daha geniş bir şekilde ele alıp incelediklerimiz dâhil olmak üzere; bütün bu tersanelerde ve deniz harekât üslerinde çeşitli büyüklükte savaş gemileri yanında, yük ve yolcu gemileri de yapılıyordu. Bilhassa Misır'daki tersaneler, donanmanın ihtiyacı olan gemiler yanında, Niliyye denilen ve Nil nehrinde yük ve yolcu taşıyan veya ihtifallerde kullanılan gemiler inşa etmekteydi. Kızıldeniz'den daha yoğun

12 Bozkurt, "Bahriye", 4/500

13 Şemsüddîn Muhammed b. Ahmed el-Beşşârî el-Makdisî, Ahsenü't-tekâsîm fî ma'rifeti'lekâlîm, thk. M. J. De Goeje (Leiden: Brill, 1906), 174.

14 Ahmed b. İshâk b. Ca'fer el-Ya'kûbî, Kitâbü'l-Büldân, thk. M. J. De Goeje (Leiden: Brill, 1892), 329; Makdisî, Ahsenü't-tekâsîm, 174.

15 Ebû'l-Kâsım Muhammed el-Bağdâdî İbn Havkal, Kitâbu Sûreti'l-arz (el-Mesâlik ve'lmemâlik), thk. J. H. Kramers (Leiden: Brill, 1938), 242; Makdisî, Ahsenü't-tekâsîm, 24-65.

16 Yâkût el-Hamevî, Mu'cemü'l-büldân (Beyrut: Dâru Sâdır, 1955), 1/785.

17 Ya'kûbî, Kitâbü'l-Büldân, 327.

18 İbn Havkal, Kitâbu Sûreti'l-Arz, 116.

19 Ebû Muîn Nâsır b. Hüsrev b. Hâris el-Mervezî Nâsır-ı Hüsrev, Sefernâme, thk. C. Schefer (Paris: Publications d'École de Langues Orientales Vivantes, 1881), 13. 
bir trafiğe sahip olan Nil'den başka Dicle ve Fırat gibi nehirlerde de gemiler çalışmaktaydı. Ünlü muhaddis Firyâbî (ö.301/913) Bağdat'a geldiği zaman kendisini "Tayyâr" ve "Zebzeb" nevinden orta büyüklükteki nehir gemileriyle karşıladılar. Dicle ve Fırat nehirleri üzerinde bu tür gemilerden oldukça fazla sayıda tekne vardı. ${ }^{20}$

Bu girișten sonra şimdi; gemi yapım limanı ve deniz harekât üssü olmaları bakımından, diğerlerine göre daha önemli, daha büyük ve daha hareketli olduğunu gördüğümüz merkezlerden Akkâ, Saydâ, Sûr ve Tarsûs deniz üsleri ve tersanelerini inceleyeceğiz.

\section{Akkâ Deniz Üssü ve Tersanesi:}

Bu merkezlerden, Akdeniz'in Suriye-Filistîn kıyılarında yer almış olanlarından ilkinin Akkâ deniz üssü olduğunu söyleyebiliriz. Akkâ, Şâm/Suriye bölgesinde ve Filistin'in güneyinde yer alan müstahkem bir kıyı şehri idi. Burası Hz. Ömer zamanına tekâbül eden 15/636 yılında Şürahbil b. Hasene (ö.18/639) tarafından fethedilmişti. Daha sonra Bizanslılar ile yapılan savaşlar sırasında tahrip edildiyse de Halife Muâviye zamanında (41-60/661680) yeniden inșa edildi. Muâviye Şâm/Suriye-Filistîn valisi iken, bölgede bulunan Bizans'tan kalma eski gemi tezgâhı havuzlarını onartarak bunları, gemi inşasına uygun hale getirtti. Böylece Akkâ o devirde İskenderiye'den sonra gemi inșasına uygun ikinci bir tersane halini aldı. Ana üsleri ve tersaneleri İskenderiye ve Akkâ olan Mısır ve Suriye-Filistîn donanmaları tam bir uyum ve insicam içerisinde hareket ediyorlardı. Abdullah İbn Ebû Serh'in kumandasında Mısır'dan veya Muâviye'nin kumandasında Suriye-Filistîn'den çıkarılan donanmalar Bizans'a karşı deniz savaş harekâtı yürütüyorlardı. ${ }^{21}$ Muâviye Kıbrıs'a karşı sevk ettiği deniz harekâtından önce Akkâ ve Sûr deniz üslerinde iyileştirmeler yaptı; bu üsleri onarttı. Ayrıca Akkâ limanı Müslümanların Akdeniz'deki ilk deniz seferleri için donanma üssü olarak kullanıldı. 28/649 yılında Kıbrıs'a, 33/654 senesinde Rodos'a düzenlenen seferler Akkâ'dan bașlatıldı. Belâzurî, Bizans Donanması'nın Suriye-Filistîn sahil şehirlerine, 49/669 yılında vuku bulan saldırısından sonra Muâviye'nin, Ürdün bölgesinin/cündünün koruma ve savunması için Akkâ'daki tersaneleri yeniden inşa ve ıslah ettirdiğini; bu tersanelerde çalışacak usta, sanatkâr ve işçilerin ikametleri için sahil şeridi boyunca evler yaptırdığını; bu dönemde (49/669) tersane inşa mühendisliğinin ve gemi yapım sanatının Mısır'a mahsus olduğunu kaydetmektedir. ${ }^{22}$ Becker de buna bağlı olarak tersanelerin Mısır'dan başka yerde bulunamayacağını iddia etmektedir. ${ }^{23}$ Muâviye'nin kurduğu ilk

20 Bozkurt, "Bahriye”, 4/500-501.

21 Belâzürî, Fütûhü'l-büldân, 154; Takıyyüddin Ahmed b Ali b Abdülkadir el-Makrîzî, elMevâiz ve'l-i'tibâr fí zikri'l-hıtati ve'l-âsâr (Bulak: Dâru't-Tibâati'l-Mısriyye, 1270), 2/190.

22 Belâzürî, Fütûhü'l-büldân, 117.

23 C. H. Becker, "Dār al-Șinā'a", Encyclopaedia of Islam (Leiden: Brill, 1913), 1/918; E. Honigmann, "Sūr", Encyclopaedia of Islam (Leiden: Brill, 1913), 4/557; F. Buhl, "Akkā", Encyclopaedia of Islam (Leiden: Brill, 1913), 1/241. 
deniz gücünün kısa zamanda gelişmesinden anlaşılıyor ki, Bizanslılar Dönemi'nde Suriye-Filistîn'de ve Mısır'da tersanelerin bulunmuş olması Müslümanların işine yaramıştır. İlk İslâmi döneme kaynaklık eden Berdî Arşivi Belgeleri ${ }^{24}$ buna delâlet etmektedir. Akkâ'daki Suriye-Filistîn Tersanesi M1sır'daki İskenderiyye Tersanesi'nden beş yll önce kurulmuştur. Çünkü Mısır Tersanesi 54/674 yılında inşa edilmiştir. ${ }^{25}$

Abdülmelik b. Mervân (65-86/685-705) Sûr'un, Kaysâriyye'nin ve Akkâ'nın daha önce harap olmuş yerlerini yeniden yaptırmıştır. ${ }^{26}$ Berdî Arşivi Belgelerİ bize, Suriye'nin Akdeniz kıyısında yer alan Lâzkiye (Lâzıkıyye)'nin, ana deniz üssü/ana bahriye merkezi olduğunu göstermektedir. Bu belgelerin 96/714 tarihli ve 1434 kayıt numaralı fıkraları bölümü, gemilerde çalışmak üzere bu merkezden hareket eden bazı denizcilere işaret etmektedir. Yine bu belgeler 12. vergi yılı baskınında Acatia ve Dromonaria ${ }^{27}$ gemilerinde bahriye hizmeti görmek üzere Afrodito ${ }^{28}$ şehrinden doğuya gönderilen dört denizcinin adını vermektedir. Bu denizciler, zikredilen tarihte Lâzkiye'den hareket etmişler ve müteakip 13. vergi yılında tekrar aynı merkeze dönmüşlerdir. ${ }^{29}$

24 Târîhu'l-Bahriyyet'l-Mısriyye isimli eser içerisinde bir bölüm olarak yayımlanan Ali Muhammed Fehmî'nin, el-Bayriyyetül-İslâmiyye fỉ Sarkı'l-Bahri'l-Mütevassit mine'lKarni's-Sâbi' ilâ'l-Âşiri'l-Mîlâdî adlı araştırması, tersaneler ve donanma üsleri alanında, dönemin orijinal kaynakları olan Arap ve Yunan dilinde yazılmış olan Papirüslerdeki kayıtlara ulaşmamızı sağlamıştır. Bu yazma belgelerin adı Berdî Arşivi Belgeleri olup, muhtelif ülkelerin müzelerinde parçalar halinde bulunmaktadır. Bu belgelerin; Berdî Arşivi Belgeleri (Berdiyyât, Berdiyyâtü Afrodito/Berlin Kurra Papirüsleri) adıyla bir araya toplanıp yayımlandığını anılan araştırmadan öğrenmekteyiz. Ayrıca bkz. N.H.Becker, Papyrusstudien, Zeitschrift für Assyriologie und Verwandte Gebiete, 1909, XXII, p.137-154; I.H Bell, Translations of the Greek Aphrodito Papyri in the British Museum, Der Islam, 1911, vol.,I I, No,1336, p.269-283,372-384, 1913, vol.,III, p.132-140, 369-373, 1913, vol.,IV, p.78-96, 1928, vol.,XVII, p.4-8

25 Ebû Ömer Muhammed b. Yusuf b. Yakub el-Kindî, Kitâbü'l-Vülât ve Kitâbü'l-Kudât, thk. Rhuvon Guest (Leiden: Brill, 1912), 339; Makrîzî, Hitat, 2/178-196; Ebü'l-Fazl Celâleddin Abdurrahman b. Ebî Bekr Süyûtî, Hüsnü'l-muhâdara fî târîhi Mısr ve'l-Kahire (Kahire: Matbaatü İdâreti'l-Vatan, 1299), 264; P. Casanova, Description historique et topographique de l'Egypte (Kahire: Institut Français d'Archéologie Orientale, 1906), 3/121 n. 1; C. H. Becker, "Cairo", Encyclopaedia of Islam (Leiden: Brill, 1913), 1/820.

26 Belâzürî, Fütûhü'l-büldân, 117-143.

27 Berdî Arşivi Belgeleri'nde; 96/714 yılında, Nil Nehri'nin ağzının/girişinin korumasını yapan donanmadan, ayrıca aynı yıl Mısır'a baskın düzenleyen donanmadan ve bir de 97/715 yllında şark donanmasından bahsedilirken, Acatia ve Dromonaria gemilerinin adı geçmektedir. Dromonaria 99/717 yılında İstanbul'u ikinci defa kuşatan İslâm donanmasının bir gemisi olarak bu donanmanın önemli bir parçasını oluşturmuştu. Bkz. H. I. Bell, "Translations of the Greek Aphrodito Papyri in the British Museum", Der Islam 4 (1913), 87, 91-92, 95-96; H. I. Bell, "Translations of tho Greek Aphrodite Papyri in the British Museum", Der Islam 17 (1928), 8.

28 Burası eskiden Aphrodito adıyla bilinen ve Eski Mısırlıların Hator (Hathor) tanrıçasının koruması altında inşa ettikleri, Yukarı Mısır'ın Tamâ şehrinin güney batısında, bu şehre yaklaşık yedi kilometre uzaklıkta bulunan Kûm Aşkût şehridir. Tanrıça Hatûr'a Yunanlılar'ın Afrodit (Aphrodite) ismini vermelerinden sonra şehir bu isimle anılmaya başlamıștır. İslam hâkimiyetine geçtikten sonra ise burası, bölgenin idari merkezi olarak Kûra ismini almıştır. Bkz. Fehmi, "el-Bayriyyetü'l-İslâmiyye", 250-251.

29 H. I. Bell, "Translations of the Greek Aphrodito Papyri in the British Museum", Der Islam 
Akkâ liman şehri/deniz üssü, Muâviye'nin halifeliğinden itibaren Hişâm b. Abdülmelik'in (105-125/724-743), tersaneyi Sûr'a nakletmesine kadar, Suriye bölgesinin tersanesi ve ana deniz üssü idi. ${ }^{30}$

Abbasiler'in Misır valisi iken daha sonra burada merkezi idareden bağımsız bir mahalli yönetim oluşturan Ahmed İbn Tolun/Tolunoğlu Ahmed (ö.270/884), Akkâ'yı Suriye’ye karşı eli altında tutmak için limanı, denize karşı taştan örtü oluşturan sağlam bir surla korumaya alarak müstahkem bir deniz üssü haline getirdi ve limanda büyük dalga kıranlar inşa ettirdi. Makdisî, İbn Tolûn'un Akkâ üssünü takviye ve tahkim için neler yaptığını eserinde kaydetmiştir. ${ }^{31} \mathrm{Bu}$ arada o, deniz limanlarının nasıl yapıldığını da ayrıntılı olarak bu eserde izah etmiștir. Çünkü Makdisî'nin dedesi bu limanları biżat inşâ eden usta bir mühendistir. Makdisî bu konuda şunları yazmaktadır;

“Ahmed Íbn Tolun Sûr'u; burasının nasıl korunduğunu/tahkim edildiğini ve limanın daire biçiminde bir duvarla nasıl çevrildiğini gördü. Akkâ için de böyle bir liman yaptırmak istedi. Bölgenin ustalarını toplayarak bu niyetini ve arzusunu onlara açtı. Cevrede, suyun içinde böyle bir limanın hiç kimse tarafindan yapılamayacağı söyleniyordu. Daha sonra usta olan dedemiz (Makdisînin dedesi) Ebû Bekir bunu yapabileceğini Ibn Tolun'a anlattı. Cevrede ise böyle bir inşaat bilgisi ve becerisi olanların bu maharetlerini göstermesi gerektiği ifade ediliyordu. Neticede İbn Tolun, Kudüs valisine bir yazı yazarak Kudüs'te oturan Ebû Bekir el-Makdisî'yi buldurtup getirtti. Huzura getirilen Ebû Bekir'e, böyle bir limanın yapımı teklif edilince, o bu konuda şunları söyledi: 'Bu gayet kolay bir işdir. Bunun için bana düzgün ve kalın dilinmiş (yarılmış) hurma kütükleri lâzım. Ebû Bekir'in isteği üzerine hazırlanan bu kütükleri, denizde suyun yüzeyine, karadaki kale duvarı genişliği kadar, birbirine bağlamak suretiyle dizerek yerleştirdi. Limanı örtecek olan bu sur temelinin denize bakan batı tarafinı, gemilerin girişini sağlamak için açık bırakarak, burayı büyük bir kapı; yani liman giriş kapısı haline getirdi. Sonra bu temelin üzerini, birbirine iyice kaynamasını sağlayan harç kullanmak suretiyle taşlarla örerek yükseltti. Yaptığı her beş sabit duba ayağı, binayı sağlam tutsun diye, kalın direklerle birbirine bağladı. Üzerine, inşa edilen duvarın ă̆ırlı̆̆ı binince suyun derinliğine doğru inen bu papuç dubaların deniz dibine oturduğundan emin olunca, iyice kuma yerleşmesi için tam bir yıl bekledi. Bir yıl sonra geldi ve inşaata bıraktı̆̆ yerden devam etti. Ínşaat eski duvarın içine girdikçe, onu eski duvarla bağlayarak sabitleștirdi. Sonra da limanın deniz tarafındaki kapısının üzerine bir kemer köprü yaptı. Gemiler Sûr'da olduğu gibi, her gece limana giriyorlar, ardından da kapıya zincir çekiliyordu." 32

Makdisî verdiği bu bilgilere, böyle bir limanın yapılıp bu tedbirlerin alın-

3 (1910), 241-242; Bell, "Translations of the Greek Aphrodito Papyri in the British Museum", 1913, 91-92.

30 Belâzürî, Fütûhü'l-büldân, 117; Yâkût el-Hamevî, Mu'cemü'l-büldân, 2/708.

31 Makdisî, Ahsenü't-tekâsîm, 162-163.

32 Makdisî, Ahsenü't-tekâsîm, 162-163. 
masından önce, burada toplanan gemilere düşman gemilerinin büyük zararlar verdiklerini; ceddi/dedesi Ebû Bekir'in bu inşaattan at ve benzeri bazı hediyelerle birlikte bin dinar aldığını ve isminin inşaata kazınarak yazıldığını, ilâve etmiştir. ${ }^{33}$

Yâkût ve Kazvînî de bu tavsifi eserlerinde harfiyen kaydetmişlerdir. ${ }^{34} \mathrm{Ay}$ rıca Kazvînî bu kayıtlara, Ebû Bekir isminin "liman koruma duvarı" üzerinde uzun süre kaldığını da ilâve etmiştir. Liman ustaları ( mühendisûn) bu yapı üslûbunu Haçlı Seferleri esnasında da aynen kullanmışlardır. Liman sığınağının girişinde yer alan, hem koruma duvarı oluşturan ve hem de dalga kıran görevi yapan bu yapının kalıntıları, büyük bir kısmı su altında kalmış olarak uzun süre yaşamıştır. ${ }^{35}$ Seyyâh Nâsırî Husrev Akkâ'daki bu limanın kapı zincirinden bahseder. ${ }^{36} \mathrm{Bu}$ zincir gemilerin limana salimen girmelerini mümkün kılacak genişlikteydi. Açllan zincir gemilerin girişinden sonra, düşman gemilerinin limana girmelerine engel olmak için, tekrar kapatılarak bağlanırdı.

\section{Saydâ ve Sûr Deniz Üsleri ve Tersaneleri:}

Saydâ ve Sûr kadim tarihlerinde uluslararası kıyı liman şehirleri olarak ün yapmış önemli şehirler olarak bilinir. Bu iki șehrin denizcileri, gemi yönetimindeki maharetleriyle ve deniz savaşlarında uyguladıkları strateji ve taktikleriyle tanınmışlardır. Emeviler Dönemi'nde, Halife Muâviye; tersanesi olmamasına rağmen oluşturduğu donanmasında yer alan gemilerini yürütmede; denizcilik konusundaki tecrübe ve ustalık geçmişlerinden dolayı, bu şehirlerin denizcilerinden önemli ölçüde yardım almıştır. Bu sebeple Emevi halifeleri, özellikle Mervân b. Muhammed (127-132/744-750) Saydâ limanının 132/750 senesinde yeniden ıslah ve onarımını (ta'mîr ve termîm) yaptırmıştır. Bu onarım ve iyileştirme faaliyeti Ziyâd b. Ebû'l-Verd eliyle tamamlanmıştır. Bununla ilgili kayıt mezkûr Saydâ limanının deniz ticaret ve savaş gemileri için önemli bir donanma merkezi ve deniz harekât üssü olması itibariyle halifelerin ilgi ve ihtimam gösterdikleri bir yer olduğuna delâlet ve ișaret eder. ${ }^{37}$ Sûr şehri bir ada üzerinde yer almaktadır. Şehre kara tarafından, ancak bir köprüden geçilen bir kapıdan girilebiliyordu. Bu kapı da hemen her tarafından doğrudan doğruya denizden yükselen sedler ile çevriliydi. ${ }^{38}$

33 Makdisî, Ahsenü't-tekâsîm, 162-163.

34 Yâkût el-Hamevî, Mu'cemü'l-büldân, 3/707-708; Zekeriyyâ b. Muhammed b. Mahmûd elKazvînî, Âsâru'l-bilâd ve ahbâru'l-ibâd, thk. F. Wüstenfeld (Göttingen: Dieterich, 1848), 148.

35 Guy Le Strange, Palestin Under the Moslems (Boston: Houghton Mifflin Harcourt, 1890), 238.

36 Nâsır-ı Hüsrev, Sefernâme, 50; Akkâ'nın tanıtımı için bkz. Ebû Abdullah Muhammed eşŞerîf b. Abdülazîz İdrîsî, Nüzhetü'l-müştâk fí ihtirâki'l-âfâk, thk. M. J. De Goeje (Leiden: Brill, 1866), 133.

37 Abdülaziz Sâlim, Dirâsetün fî Târîhi Medîneti Saydâ fi'l-Asri'l-İslâmî (Beyrut: Câmiatu Beyrut, 1970), 64; Sâlim, el-Bahriyyetü'l-İslâmiyye fî Misr ve'ş-Şâm, 50.

38 Honigmann, "Sūr", 4/557; Türkçe çevirisi için bkz. E. Honigmann, "Sûr", Milli Eğitim Bakanlığı İslam Ansiklopedisi (İstanbul: Milli Eğitim Basımevi, 1979), 11/42. 
İslâm coğrafyacıları eserlerinde Sûr'u şöyle tavsif ve tarif etmişlerdir:

"Sûr güzel ve bereketli bir șehirdir. Orada kendilerine tahsis edilen yerlerde çok çalışkan ve mahir ustalar oturmaktadır. Sûr ve Akkâ arasında bir körfez uzanmaktadır. Bu yüzden Sûr ve Akkâ'nın birbirine bakan, karşılıklı olarakyer almış iki şehir olduğu hep söylenir. Fakat kıyı boyunca hareket edip Sûr'a ulaşmak oldukça zordur."39

Sûr limanı Emeviler'in Mervânî kolundan gelen halifeler döneminde, bir deniz üssü (el-Merkezü'l- Bahrî) olan Akkâ'nın yerini almıştır. Sûr'un bu durumu Abbasi Halifesi Mütevekkil-Alellâh zamanına (232-247/847-861) kadar devam etmiștir. ${ }^{40}$ Belâzurî tersanenin Akkâ'dan Sûr'a nakledilişinin sebebi olarak şunları kaydeder: Halife Hişâm b. Abdülmelik Muaytoğulları ailesine mensup birisinden gemi yapımında yardımcı olan değirmen cihaz ve aletleri ile hangarlar ve depoları satın almayı istediğinde, o şahıs bunları satmaya yanaşmayınca bu defa o, tersanenin, gemi iskelesinin ve gemi yapımına uygun alet/araç-gereç ve elemanların Sûr'a nakledilmesini emretti. Hişâm tersâneyi Sûra naklettirdi ve burada ambarlar ve tersane havuzları kurdurdu". ${ }^{41}$

İslâm coğrafyacıları Sûr'un, Suriye-Filistîn sahilinde bulunan koruma ve savunma tedbirleriyle gayet iyi bir şekilde tahkim edilmiş korunaklı bir şehir olduğunu eserlerinde belirtmişlerdir. Bunlardan Ya'kûbî, Sûr'un ünlü bir sahil șehri olduğunu; burada bir tersânenin inşâ edildiğini; Halîfe'nin deniz harp filosunun Bizans saldırılarına cevap vermek üzere bu üsden denize açıldığını; buranın mevcut koruma tedbirleri ve istihkâm donanımlarına rağmen güzel bir şehir olduğunu, kaydetmektedir. ${ }^{42}$ Kudâme de, Ürdün'ün kıyı şehirlerinin Sûr ve Akkâ şehirleri olduğunu, Sûr'a gemi yapımı için tersaneler inşâ edildiğini, yazmaktadır. ${ }^{43}$ Ya'kûbî ve Kudâme Sur'da tersane olduğundan bahsetmekte, fakat muahhar İslâm coğrafyacıları bundan söz etmemektedirler. Makdisî ise, Sûr'un, deniz yönünden gelen saldırılara karşı koruma tedbirleri ile donanmış müstahkem bir şehir olduğunu; deniz tarafindan karaya köprü (iskele) ile bağlantılı bir girişinin bulunduğunu; şehrin her bakımdan denizle kuşatılmış olduğunu; limanının üç taraftan duvarlarla korumaya alındığını; açık olan kı-

39 Ebû Bekr Ahmed b. Muhammed el-Hemedânî İbnü'l-Fakîh, Kitâbü'l-Büldân, thk. M. J. De Goeje (Leiden: Brill, 1885), 59; İbn Havkal, Kitâbu Sûreti'l-Arz, 114; Nâsır-ı Hüsrev, Sefernâme, 46-50; Muhammed b. Ahmed el-Endelüsî İbn Cübeyr, Rihletü İbn Cübeyr, thk. M. J. De Goeje (Leiden: Brill, 1908), 304-305; Yâkût el-Hamevî, Mu'cemü'l-büldân, 1955, $3 / 433$.

40 Belâzürî, Fütûhü'l-büldân, 118.

41 Belâzürî, Fütûhü'l-büldân, 118; Yâkût el-Hamevî, Mu'cemü'l-büldân, 1955, 3/708.

42 Ya'kûbî, Kitâbü'l-Büldân, 327.

43 Ebû'l-Ferec el-Kâtib el-Bağdâdî Kudâme b. Ca'fer, "Nübez min Kitâbi'l-Harâc ve sınâ'ati'lkitâbe li-Ebi'l-Ferec Kudâme b. Ca'fer el-Kâtib el-Bağdâdî", Kitâbü'l-Mesâlik ve'l-Memâlik, thk. M. J. De Goeje (Leiden: Brill, 1889), 255. Kudâme b. Ca'fer'in Kitâbü'l-Harâc'ının bazı bölümleri M. J. de Goeje tarafından İbn Hurdazbih'in el-Mesâlik ve'l-memâlik adlı kitabının neşrine eklenmiștir. 
sımdan gemiler limana girdikten sonra, bu kısmın akşamleyin büyük ve kalın bir demir zincirle kapatıldığını kaydetmektedir. ${ }^{44}$

Saydâ deniz üssünün, Abbasi Halifesi Mütevekkil-Alellâh'ın (242247/847-861) da ilgi ve desteğini kazandığını ve Halife'nin gemi yapımını emrettiği bütün sahil şehirleri içerisinde, burasının da yer adığını görmekteyiz. Abbasi Devleti Saydâ kıyılarının savunulması vazifesini garb bölgesi ümerasından Arslânî veya Tenûhî ailesinin ferdlerine yüklemiştir. Evvelemirde bu vazife 257/871 senesinde Emîr Nu'mân b. Âmir el-Askalânî'ye verilmiștir. ${ }^{45}$ Garb kumandanlığı Beyrut, Saydâ ve bu iki mıntıkanın dağlarını içine alıyordu. Bu görev Abbasi Halifesi Mu'temid-Alellâh'ın (256-279/870892) Şâm ve tevâbii valiliğine atanmış olan Amacur et-Türkî’nin (ö.264/879) emriyle gerçekleșmiştir.46 Emîr Nu'mân bu görevi Amacur'un 264/879 yılında ölümüne kadar yürütmüştür. Daha sonra bu vazifeyi Ahmed b. Tolun yürütmüştür. Emîr Nu'mân Saydâ ve Beyrût'a çok iyi sahip olmuş ve bu yüzden cesur bir kumandan olarak tanınmıştır.

Abbasi halifeleri Bizans saldırılarından sürekli endişe duydukları için, böyle bir tehlikeye karşı, Emeviler'in Sûr üssünde inşa ettikleri tersaneleri koruma altında tuttular. Lâkin Halife Mütevekkil 247/861 yılında bu tersaneleri Akkâ üssüne naklettirdi. ${ }^{47}$

Halife Mütevekkil'in, donanma kıtalarını ve diğer bahriye kuvvetlerini sahil şehirlerine dă̆ıttı̆̆ını görmekteyiz. ${ }^{48}$ Makdisî Müslüman esirlerin fidye karşılığı serbest bırakılmak üzere Bizans gemileriyle nakledilmeleri esnasında, buradaki gözetleme istasyonlarını/ribâtları (revâbît) anlatırken şunları söylemektedir:

"Keferselâm Kaysâriye'nin, kasabalarından biridir. Bu kasabada cihâd için gelen gönüllülerin bulunduğu ribâtlar vardır. Buraya karşı, içerisinde Müslüman esirler bulunan Bizans'ın büyük güverteli savaş gemileri (șelendiyât) ve kadırga türü gemileri (șevânî) yelken açarlardı. Bizans'ın bu gemileri kasaba önlerinde görününce ribâttaki topluluklar arasında, bir gürültü ve hareketlilik başlardı. Eğer vakit gece ise, ribâtın kulesinde ateş yakılırdı. Vakit gündüz ise, kuleden duman tüttürülürdü. Kasabaya kadar kıyı șeritindeki her ribâtın, içerisine görevlilerin yerleştirildiği yüksek kuleleri vardı. Bu kulelerden birinde yakılan ateşin alevini veya tüten dumanını gören öbür kule de kendi ateșini

44 Makdisî, Ahsenü't-tekâsîm, 163-164; Ebû Abdullah Şemseddin Muhammed b. Abdullah İbn Battuta, Tuhfetü'n-nezâir fî garâibi'l-emsâr ve acâibi'l-esfâr (Rıhletu İbn Batûta), thk. Defremeri-Sanguinetti (Paris: Imprimerie Nationale, 1893), 1/131. Bu zincir Bizans donanmasına ait gemilerin limana girişini engellemek içindir. Bkz., Şeybânî, el-İkrâh, elMektebetü'lCoğrâfiyyetü'l-Arabiyye, (Leyden 1889), III,162-163

45 Sâlih b. Yahyâ, Târîhu Beyrut (Beyrut, 1968), 41.

46 Tannus b. Yusuf b. Mansur eș-Şidyak, Ahbâru'l-a'yân fî Cebeli Lübnân (Beyrut: Metâbiu Semya, 1954), 2/283.

47 Belâzürî, Fütûhü'l-büldân, 118.

48 Belâzürî, Fütûhü'l-büldân, 118. 
yakardı (ve dumanını tüttürürdü). Bunu gören diğeri de aynı şeyi yapar; böylece kuleler arası haberleşme sağlanır ve düşman gemilerinin geldiği onlara da duyurulurdu. Bir saat içerisinde durum kasaba halkına duyurulur ve savunma savaşı için toplanmaları sağlanırdı. Kulelerde ayrıca davul çalınmak suretiyle de kasaba sakinlerinin ribâtta toplanmaları sağlanırdı. Neticede insanlar silâhları ve diğer donanımlarıyla çıkagelirlerdi." 49

\section{Tarsus Deniz Üssü ve Tersanesi:}

Doğu Akdeniz'in Suriye-Filistîn sahillerindeki bahriye kuvveti ve donanma merkezlerinden biri olan Tarsûs önemli bir deniz harekât üssü idi. ${ }^{50}$

İslâm coğrafyacılarının Tarsus'u şu ifadelerle tarif, tavsif ve tasvir ettiklerini görürüz. Bunlardan Nâsırî Husrev, Tarsûs'un çok güzel hir yerde olduğunu, denize yüksekten bakan üç yönünün bulunduğunu, doğu tarafinda, burçlarında savunma için kullanılan harp alet ve cihazlarının/silâhlarının bulunduğunu, bir kalesinin olduğunu, çünkü halkın Bizans saldırılarından endişe ettiğini kaydetmektedir. ${ }^{51}$

Mes'udî Tarsûs'un yerini, şu ifadeleriyle belirtmektedir: "es-Suğûru'ş-Şâmiyye'yi belirleyen ve bir nehir olan Berdân Irmă̆ı Tarsûs şehrini ikiye bölerek geçer ve şehre altı mil esafede denize dökülür."52 Yâkût da, Berdân Irmağı'nın aynı mesafede denize döküldüğünü belirtmektedir. ${ }^{53}$

Istahrî ise; Evlâs'tan çıkınca sahile uzanan dağlar üzerinde Bizans'a ait Kulmiye adında bir şehrin bulunduğunu; Tarsûs'un bazı kapılarına bu şehre nispeten Kulmiye adının verildiğini; Kulmiye'nin ne denizde ve ne de deniz klyısında bir yer olmadığını; buranın deniz kıyısında yer alan ve Lâmis adıyla bilinen bir yere yakın olması dolayısıla bir anlamda onun yerini tuttuğunu; yani Lâmis'e Kulmiye dendiğini; Lâmis'in esir değişim/mübâdele yeri olduğunu; Rumlar'ın deniz yoluyla gelerek gemilerdeki Müslüman esirleri deniz tarafindan iade ettiklerini; bunlara karşılık Müslüman taraf da ellerindeki Rum esirleri kara tarafindan Bizans gemilerine verdiklerini, kaydetmektedir. ${ }^{54}$

Kaynakların, Tarsûs'un askeri bakımdan jeo-stratejik konumunu șu şekilde belirttiklerini ve ortaya koyduklarını görüyoruz:

Belâzurî; kumandan Hasan b. Kahtabe et-Tâînin (ö.162/778), Horasanlı, Musullu ve Şâm/Suriyeli askerlerin başında olduğu halde162/779 yılında, Yemen'den gelen imdat kuvvetleri ve ayrıca Irak ve Hicaz gönüllülerinin de deste-

49 Makdisî, Ahsenü't-tekâsîm, 177.

50 Bekrî, Abdullah b. Abdülazîz b. Muhammed Ebû Ubeyd el-. el-Mugrib fî zikri bilâdi Ifrikıyye ve'l-Magrib min Kitâbi'l-Mesalik ve'l-Memâlik. thk. M. G. De Slane. (Paris-Cezayir: Typographie Adolphe Jourdan, 1911), II,453; Yâkût, Mu'cem, III,526

51 Nâsır-ı Hüsrev, Sefernâme, 13.

52 Mes'ûdî, Mürûcü'z-zeheb, 1861, 1/58.

53 Yâkût el-Hamevî, Mu'cemü'l-büldân, 1955, 1/553.

54 İstahrî, Kitâbüll-Mesâlik ve'l-Memâlik, 69; İbn Havkal da aynı tanıtımı yapmaktadır. Bkz. İbn Havkal, Kitâbu Sûreti'l-Arz, 201. 
ği ile Bizans topraklarında savaşarak Tarsus'a kadar geldiğini; Halife Mehdî̀ye, (158-169/775-785) buranın yapım ve onarımı, düşmana karşı korunması, hiç para esirgemeden buraya Íslâm'ın müdafası için savaşçılar yerleştirmek suretiyle emniyete alınması, düşmanın buraya vaki saldırılarının, harp taktik ve tekniklerini kullanarak püskürtülmesi konularını içeren bir rapor gönderdiğini; kumandan Hasan b. Kahtabe'nin buradaki gaziler ve bütün bu belirttiği konularda yapılması gerekenleri üstlenerek sırtına hayli yük aldığını, yazmaktadır. ${ }^{55}$

Aynı yazar eserine aldığı bir başka anlatımda da; kumandan Hasan b. Kahtabe et-Tâî'nin Bizans ülkesinde hareket ederek Tarsûs'a geldiğini; buranın harap olmuş halini gördüğünü; şehre baktığını; her tarafını dolaştığını; şehrin sakinlerini saydırttığını ve bunların 100 bin kişi olduklarını gördüğ̈̈nü; hilâfet merkezine dönüp Mehdînnin huzuruna çıktığında buranın durumunu; şehrin yapım ve onarımının ve düşman saldırısına karşı savunma tedbirleriyle donatılarak emniyete alınmasının gerektiğini; bura ahalisinin ve İslâm'ın izzetinin korunması gerektiğini ona anlattı̆̆ını, kaydetmektedir. ${ }^{56}$

Aynı kumandan bir diğer konuşmasında da, șehrin yapımı ve onarımı konusundaki arzusunu Halife'ye anlattı̆̆ını ve neticede Halife'nin şehrin onartmını emrettiğini; daha sonraki yıllarda (171/787 yılında), Rumlar/Bizans'ın Tarsûs'a çıkarak buranın tahkimi ile şehre savaşçılar yerleştirilmesi konularını aralarında istişare ettikleri bilgisi Hârûn Reşîd'e ulaşınca, Halife'nin Herseme b. A'yân'a; 'Bizans üzerine yaz seferlerine (savâif) çıkması' emrini verdiğini; Tarsûs'a giderek orayı onarmasını emrettiğini; Herseme'nin de söyleneni hemen yaptığını; Ferec b. Süleym el-Hâdim'i bu onarımın yürütülmesi ile görevlendirdiğini ve böylece Tarsûs'un 172/788 yılında yeniden onarıldığını; Müslümanlar'ın burada ikamet ettiklerini ve şehre bir de mescid yapıldığını, kaydetmektedir. ${ }^{57}$

Tarsûs'un tamir ve tahkiminin yenilenmesi Hârûn Reşîd'in (170193/786-809) eliyle 171/787 yılında tamamlandı. Yapımı tamamlanınca sayıları 3.000 civarında Horasanlılardan oluşan bir birlik, ayrıca 1.000 kişilik Massîsalı (Mopsesteia, Misis) bir başka birlik ve 1.000 kişilik de Antakya'lı bir diğer birlik şehrin savunması için Tarsus'a getirilip yerleştirilmiş ve bu birliklere iktâlar tahsis edilmiştir. Tarsûs'un, bu tarihten sonra önemli bir merkez, bir ribât ve Şam Suğûru adıyla bilinen Suriye bölgesi Íslâm-Bizans sınır hattı üzerinde yer alan, Abbasiler'in en büyük deniz üssü haline geldiğini görmekteyiz. ${ }^{58}$

55 Belâzürî, Fütûhü'l-büldân, 169; İbnü'l-Fakîh, Kitâbü'l-Büldân, 113.

56 Belâzürî, Fütûhü'l-büldân, 169.

57 Belâzürî, Fütûhü'l-büldân, 189-190; İbnü'l-Fakîh, Kitâbü'l-Büldân, 113; Ebü'l-Hasan Ali b Hüseyin b Ali el-Mes'ûdî, Mürûcü'z-zeheb, thk. C. Barbier de Meynard - Pavet de Courteille (Paris: Imprimerie Nationale, 1861), 1/294-295; Ebü'l-Hasan Ali b Hüseyin b Ali elMes'ûdî, et-Tenbîh ve'l-işrâf (Leiden: Brill, 1894), 189.

58 Ahmed b. İshâk b. Cacfer el-Ya'kûbî,,Târîh, c.I-II. Beyrut 1960, II,410; Muhammed b. Cerîr b. Yezîd et-Taberî, Târîhu'l-ümem ve'l-mülûk (Beyrut, ts.), 10/50; Sâlim, el-Bahriyyetü'lİslâmiyye fî Misr ve'ş-Şâm, 52. 
Makdisî, Tarsûs'un Küçük Asya ile Suriye arasında yer alması sebebiyle Islâm Dünyası ile Hristiyan Dünyası'nı ayıran bir hat konumuna sahip olduğunu, kaydetmektedir. ${ }^{59}$ İslâm coğrafyacıları ise Tarsûs'un, es-Suğûru'ş-Şâmiyye ve el-Avâsım zincirinin bir halkası olduğunda birleşmektedirler. ${ }^{60}$ İbnü'l-Fakîh ve Ebû'l-Fidâ, Tarsûs'un, Suriye sahili üzerinde bulunduğunu, nakletmektedirler. ${ }^{61}$

Civar memleketlerden sürekli olarak göçmenlerin gelmesiyle şehir sakinlerinin sayısı gittikçe artmış; şehir gelişerek zenginleşmiş ve büyümüştür. Onlar bu șehre, ölünceye kadar Allah yolunda savaşmak gibi dini-hamâsi duygularla geliyorlardı.

Istahrî, Mes'ûdî ve İbn Havkal, şehrin H.IV./M.X. yüzyıldaki durumu hakkında geniş bilgi vermektedir. ${ }^{62}$

İbn Havkal, Istahrî̀nin anlatımlarını naklederek bu anlatmalara șunları ilâve etmiştir:

“Tarsûs ünlü ve büyük bir şehirdir. Me'mûn onu yeniden imar etmiş; daha mükemmel ve medeni bir hale getirmiş ve şehrin etrafinı iki sur ile çevirmiştir. Tarsûs ordugâhında at, asker, mühimmat, savaş malzemesi (ikmal, levazım), harp filosu, hayvan, silâh, mahsul, bolluk ve zenginlik başka yerde olduğundan çok daha fazla bir şekilde vardır. Tarsus üssünden hareket eden orduların karada ve denizde yaptığı savaşların hepsinde, bu konuda bilgi veren eserlerin tahkiki ve haberlerin tasdikiyle belirlendiği gibi; zafer, bol ganimet, düşmanı kırıp yok etme gibi neticeler elde edilmiştir. Burada karşımızda Sicistan, Kirman, Faris, Huzistan, Rey, Isfahan, Taberistan, Cezire, Azerbaycan, Irak, Hicaz, Suriye, Misır, Mağrib büyüklüğünde bir șehir yoktur. Ancak bütün bu bölgelerden gelenlerin burada aileleriyle birlikte kalabilecekleri bir evleri ve gazâ/ cihâd için gelenlerin kalabilecekleri ribâtları vardır."63

Taberî, Halîfe Mu'tezıd'ın (279-289/892-902), Vasîf el-Hâdim'in 287/900 yılındaki ihtilâl girişimini şiddetli bir şekilde nasıl bastırdığını naklettikten sonra şunları ilâve etmektedir:

“Halife el-Mu'tezıd, Müslümanların deniz savaşına çıktıkları bütün gemilerinin/donanmalarının/harp filolarının yakılmasını emretti. Yâzmân'ın gulâmı olan Dimyâne; Halîfe'nin Tarsuslulara karşı, içinde tuttuğu, gizlediği ve açı̆̆a

59 Makdisî, Ahsenü't-tekâsîm, 14-15.

60 Ebû Ali Ahmed b. Ömer İbn Rüste, el-A'lâkü'n-nefise, thk. M. J. De Goeje (Leiden: Brill, 1891), 7/97; Kudâme b. Ca'fer, "Nübez min Kitâbi'l-Harâc", 253; Ebû İshak İbrâhim b. Muhammed el-Fârisî el-Kerhî İstahrî, Kitâbü'l-Mesâlik ve'l-Memâlik, thk. M. J. De Goeje (Leiden: Brill, 1927), 35; Mes'ûdî, Mürûcü'z-zeheb, thk. C. Barbier de Meynard, 8/44; İbn Havkal, Kitâbu Sûreti'l-Arz, 198; Yâkût el-Hamevî, Mu'cemü'l-büldân, 1955, 1/927.

61 İbnü'l-Fakîh, Kitâbü'l-Büldân, 7; İmâdüddin el-Melikü'l-Müeyyed İsmail b. Ali Ebü'l-Fidâ, Takvîmu'l-Büldân, thk. M. G. De Slane (Paris, 1840), 248-249.

62 İstahrî, Kitâbü'l-Mesâlik ve'l-Memâlik, 63; Mes'ûdî, et-Tenbîh ve'l-işrâf, 351; Mes'ûdî, Mürûcü'z-zeheb, 1861, 1/1-2.

63 İbn Havkal, Kitâbu Sûreti'l-Arz, 123. 
vurmadığı bir şeyden dolayı bütün bu gemileri yaktığını söylemektedir. Burada o zaman elli kadar gemi vardı ki, bunlara çok büyük paralar harcanmıştı. Neticede bütün bunlar yakıldı. Müslümanlar bundan büyük zarar gördüler ve güçleri kırıldı. Rumlar ise kuvvet buldular ve deniz savaşlarında hezimete uğramaktan artık emin oldular." 64

Bu gemilerin yakılmasının arkasındaki gizli sebepler acaba neydi? Taberî'nin yukarıda naklettiğimiz bu rivayeti Tarsûs'un Bizanslılar'a karşı sürdürülen harekâtta çok önemli bir deniz üssü olduğuna işaret etmektedir. $A b$ basi halifeleri Bizans'a karșı yürüttükleri kara harekâtını bu merkezdeki deniz kuvvetleriyle ikmal ediyorlard ${ }^{65}$

Kudâme, Tarsûs'un Bizans'a karșı karada ve denizde yürütülen savaş harekâtının yapıldığı Suğur eş- Şâmiyye içerisinde yer aldığını, kaydeder. ${ }^{66}$

Mes'ûdî bu konuda şunları kaydetmektedir: "Tarsûs Emiri Yâzmân el-Hâdim (ö.278/891) kara ve deniz savaşlarında gayet başarılı bir kumandandı. Beraberinde eşine rastlanmamış güçte ve kuvvette deniz askerleri vardı. Düşman onun her zaman galip geleceğini düşünüyordu. Düşmanın kafasında onun her zaman zafer elde edeceği fikri iyice yerleșmiști. Düșman ondan korkuyordu. Hıristiyanlar almış oldukları kendi savunma ve korunma tedbirleri içerisinde bile birşey yapamayacakları endişesini her zaman taşıyorlardı; Suğûr el-Cezeriyye'nin Malatya hâkimi/emîri Amr b. Ubeydullâh b. Mervân el-Aktâ've Suğûr eş-Şâmiyye'nin hâkimi/sâhibi Ali b. Yahyâ el-Ermenî'den sonra Bizans'a karşı Yâzmân el-Hâdim'den daha ileri bir atılıma yükselmediler."67

Taberî’nin işaret ettiği; bu gemilerin hasara uğramasının ortaya çıkardığı kötü tesire rağmen, Tarsus'ta üslenen Suriye İslâm Donanması, III./X. yüzyılın sona ermesinden önce Ege Denizi'ndeki Bizans Donanması'nın korku kaynağı durumundaydı. ${ }^{68}$ Taberî, Ebû Ma'dân'ın 10 Ramazan 291/26 Haziran 904 tarihinde yazdığı; Tarsus'ta aldığı haberleri vezire anlatmasını içeren bir hitabeye işaret etmektedir; hitabede şunlar yer almaktadır:

“Allah Rumlar'ın/Bizanslılar'ın bu vakitte Antalya şehrinde yaptı̆̆ı savaşta bilinenleri Ğulâm Zarâfe'ye gösterdi. Antalya'nın Konstantıniyye'ye denk bir şehir olduğunu anlatırlar. Bu şehir deniz kıyısındadır. Ğulâm Zarâfe burayı kılıç yoluyla savaşarak (anveten) aldı. Bu savaşta beş bin kişi öldürüldü; bir o kadar da esir edildi. Müslümanların elindeki esirlerin dört bin kadarı serbest bırakıldı. Burada Rumlar'a ait altmıș pare gemiye el kondu. Bu gemilere altın,

64 Muhammed b. Cerîr b. Yezîd et-Taberî, Târîhu'l-ümem ve'l-mülûk (Beyrut, ts.), II/369-370; İbnü'l-Esîr, el-Kâmil fi't-târîh, thk. Johannes Tornberg, 7/335, 344.

65 Kudâme b. Ca'fer, "Nübez min Kitâbi'l-Harâc", 259.

66 Kudâme b. Ca'fer, "Nübez min Kitâbi'l-Harâc", 253; Steven Runciman, The Emperor Romanus Lecapenus and His Reign: A Study of Tenth-Century Byzantium (Cambridge: Cambridge University Press, 1929), 123.

67 Mes'ûdî, Mürûcü'z-zeheb, 1874, 8/72.

68 E. W. Brooks, "The relations between the empire and Egypt from a new Arabic source", Byzantinische Zeitschrift 22/2 (1913), 384. 
gümüş, emtia ve köleler yüklendi. Bu savaşa katılan her askerin ganimetlerden aldığı pay 1.000 dinarı buluyordu. Müslümanlar bu savaşta elde ettikleri galibiyet ve ganimetlerden dolayı sevindiler."69

İbnü'l-Esîr ve İbn Haldûn, aynı rivayeti kesik kesik zikrederek, Ğulâm Zarâfe'nin bu deniz harekâtına Tarsûs'tan hareketle başladığını ve bu donanma kumandanının on bin bahriye askeriyle ve elli dört pare büyük gemiden oluşan donanmasıyla Sâlûnik/Selânik'e hücûm eden Leo et-Trablûsî'den başkası olmadığının anlaşıldığını, kaydetmektedirler. ${ }^{70}$ Bunu Bizans tarihçisi Cameniates de kaydetmektedir. Bahsi geçen Antalya, ${ }^{71}$ İslâm ülkesi dolaylarında, Sâlûnîk (Selânik) ise Bizans dolaylarında yer alan şehirlerdi. Çünkü Antalya'dan başka Konstantıniyye'ye ${ }^{72}$ denk bir şehir buralarda bulunmuyordu. Buna ilâve olarak şehre yapılan ve fetihle neticelenen bu harekâtla ilgili olarak İslâm tarihçilerinin verdiği tarih ile Bizans tarihçilerinin verdiği tarih birbirini tutmaktadır. ${ }^{73}$

Mes'ûdî, Lâvî et-Trablûsîi ${ }^{74}$ olarak kaydettiği Leo et- Trablûsî'nin Akdeniz'de harp gemileri/harp filosu kumandanlığını yürüten Ebû'l-Hâris Ğulâm Zarâfe olduğunu kaydetmektedir. ${ }^{75}$ İslâm Donanması'nın Selânik baskınında elde ettiği zafer, Müslümanların o dönemde, Akdeniz'deki üstünlüklerinin delili sayılır. IV./X. asır henüz gelmeden, Akdeniz'deki hâkimiyetin, tamamen Müslümanların eline geçtiğini söyleyebiliriz.

Belevî, İbn Tolûn'un Tarsûs üssünden hareket eden bahriye kuvvetinden korkusunun, onu kendi (Tolûnlu) donanmasını takviyeye sevk eden müessir sebeplerden biri olduğunu kaydetmektedir. ${ }^{76}$ Makrîzîi ${ }^{77}$ ise, İbn Tolun'un bu; konuyla ilgili olarak elde ettiği şu haberleri de buna ilâve etmektedir: "Tarsûs Donanması, Muhammed b. Süleyman'ın deniz harekâtına iştirak eden Dimyâne'nin komutası altındaydı. Bu donanma Tolunlu Donanması'nı önce Tinnis'te, daha sonra da Dimyat'ta 291/904 yılında helâk etmiş ve gemilerini, içerilerin-

69 Taberî, Târîhu'l-ümem ve'l-mülûk, 12/5; Arîb b. Sa'd, Sılatü Târîhi't-Taberî, thk. M. J. De Goeje (Leiden: Brill, 1897), 6.

70 İbnü'l-Esîr, el-Kâmil fi't-târîh, 1965, 7/368-369; Abdurrahmân b. Muhammed İbn Haldûn, Kitâbü'l-İber ve divanü'l-mübtede ve'l-haber fî eyyami'l-Arab ve'l-Acem ve'l-Berber ve men asarahum min zevi's-sultani'l-ekber (Beyrut, 1971), 2/357; R. J. H. Jenkins, "The 'Flight' of Samonas", Speculum 23/2 (1948), 267. ; Fehmî, 362

71 İbn Haldûn, Kitâbü'l-İber, 2/357; Arîb b. Sa'd, Sılatü Târîhi't-Taberî, 6.

72 Fehmî, 362;Gustave Léon Schlumberger, Un empereur byzantin au dixième siècle: Nicéphore Phocas (Paris: E. de Boccard, 1923), 123; Runciman, The Emperor Romanus Lecapenus and His Reign, 123.

73 Jenkins, “The 'Flight' of Samonas”, 230-235.

74 Lâvî (Leo kelimesinin Arapçalaşmış şeklidir) et-Trablûsî’nin Tarsûs'daki Bizans komutanlarının büyük çoğunluğunun, esir alındıktan sonra Müslüman olanlarından biri olduğu anlaşılmaktadır.

75 Mes'udî, Mürûcü'z-zeheb, 1861, 1/282.

76 Ebû Muhammed Abdullah b. Muhammed b. Umeyr el-Belevî, Siretü Ahmed b. Tolun, thk. Muhammed Kürd Ali (Dımaşk: el-Mektebetü'l-Arabiyye, 1947), 78.

77 Makrîzî, Hitat, 2/180. 
deki her şeyle birlikte esir almiştı."78 Kindî de, Ğulâm Zarâfe (Leo et-Trablûsî) adiyle bilinen Raşîk el-Verdânî́nin bu harekâtta Dimyâne'yle birlikte olduğunu, ${ }^{79}$ Dimyâne'nin 293/905 yılında Muhammed b. Halîc'in direnişini kırma konusunda Fatımi halifesine yardım etmek için Mısır'a müteveccihen Tarsûs'tan hareket ettiğini, kaydetmektedir. ${ }^{80}$ Mes'ûdî de Dimyâne'den bahsetmekte ve şöyle demektedir: "Dimyâne Akdeniz'de hareket eden donanmanın kumandanıdır, 297/909 yılında Rûm denizinde savaş harekâtı yürüten (sâhibu'l-ğazv) Dimyâne Müslüman Donanması'na ait gemilerde Kıbrıs adasında savaşmıştır. Dimyâne Kıbrıs adasında dört ay kalmıştır. Burada esir alıp baskın yapmış ve buranın müstahkem kalelerini fethetmiştir."81

Fatımi halifesi, kumandanı olan Süleyman el-Hâdim'i 307/919 yılında Mısır Savaşı'na gönderince, Tarsûs Donanması, deniz amirali Semel el-Hâdim'in kumandasında çıktığı deniz harekâtında, Kuzey Afrika hâkimi Mehdî el-Alevî’nin gemilerini neft/yanıcı petrol gazı fırlatarak yakmış; Mehdî’nin bahriye askerleri öldürülmüş ve bir kısmı da esir alınmıştı. ${ }^{82} \mathrm{Bu}$ savaşta donanma, Eutychius'un belirttiğine göre, 80 pare harp gemisinden oluşuyordu. ${ }^{83}$ İbnü'l-Esîr'in kaydettiğine göre, Semel el-Hâdim Akdeniz Donanması'nın kumandanıydı. ${ }^{84}$ Mes'ûdî buna; Semel el-Hâdim'in daha çok Zülfâ adıyla ün yaptığını eklemekte ve Tarsûs'tan hareket eden donanmaya komuta ettiğine; Tarsûs'lu askerlerin ona refakat ettiğine işaret etmekte ve ondan emîru's-suğûr/sugûur kumandanıymış gibi bahsetmaktedir. ${ }^{85}$ Bu bilgilerden hareketle biz, Tarsûs'un Tolunoğulları ile Abbasiler arasında el değiștirdiğini söyleyebiliriz.

Bütün bu açıklamalar ve verilen bilgiler bize, Tarsûs'un son derece önemli bir deniz üssü olduğunu ve Abbasiler'in bu üsden hareketle Bizans üzerine deniz seferleri sevk ettiğini göstermektedir. Tarsûs, II. Nikephoros Phokas'ın (M.S.963-969), 354/965 yılında burasını geri aldığı zamana kadar Abbasiler'in elinde kalmıștır. Yâkût'un kaydettiği gibi, Nikephoros burada Emeviler Dönemi'nden beri toplanan benzeri görülmemiş ve duyulmamış hazineleri ele geçirmişti. ${ }^{86}$

78 Kindî, Kitâbü'l-Vülât, 245-246; Arîb b. Sa'd, Sllatü Târîhi't-Taberî, 7; Ebû Ali Ahmed b. Muhammed b. Ya'kûb b. Miskeveyh İbn Miskeveyh, Tecâribü'l-ümem ve teâkiübu'l-himem, thk. Ferecullâh Zeki el-Kürdî (Mısır, ts.), 5/42; İbnü'l-Esîr, el-Kâmil fi't-târîh, thk. Johannes Tornberg, 1965, 7/370; İbn Haldûn, Kitâbü'l-iber, 2/310; Makrîzî, Hıtat, 1/322; Ebü'lMehâsin Cemâleddin Yûsuf b Tagriberdî İbn Tagrîberdî, en-Nücûmü'z-zâhire fî mülûki Misr ve'l-Kahire (Kahire, 1972), 3/136.

79 Kindî, Kitâbü'l-Vülât, 245.

80 Kindî, Kitâbü'l-Vülât, 260, 262-263; Makrîzî, Hitat, 1/322.

81 Mes'ûdî, Mürûcü'z-zeheb, 1874, 8/282.

82 Takıyyüddin Ahmed b Ali b Abdülkadir el-Makrizî, Itttiâzü'l-hunefâ bi ahbâri'l-hulefâ, thk. Cemâleddin eş-Şeyyâl (Kahire: Dârü'l-Fikri'l-Arabi, 1948), 43.

83 Saîd b. Bıtrîk, et-Tarihu'l-mecmû' ale't-tahkik ve't-tasdik, 1860, 80; İbn Haldûn, Kitâbü'lİber, 2/310; Makrizî, İttiâzü'l-hunefâ bi ahbâri'l-hulefâ, 43.

84 İbnü'l-Esîr, el-Kâmil fi't-târîh, thk. Johannes Tornberg, 8/89, 118.

85 Mes'ûdî, Mürûcü'z-zeheb, thk. C. Barbier de Meynard - Pavet de Courteille, 2/16-17.

86 Mes'ûdî, Mürûcü'z-zeheb, thk. C. Barbier de Meynard - Pavet de Courteille, 3/526-527. 


\section{Sonuç}

24/645 senesinde Bizanslılar'ın bir çıkarma harekâtı sonunda İskenderiye’yi ele geçirmeleri üzerine; Bizans'a karşı mücadelenin, bahriye kuvvetinin/donanmanın desteğini almadan yürütülemeyeceğini fark eden ilk devlet adamı Muâviye b. Ebû Süfyân olmuștur. İslâm denizciliği ve buna bağlı olarak İslâm donanması oluşturma faaliyetinin, daha Muâviye'nin Şâm/Suriye-Filistin valiliği sırasında, ele geçirilen sahillerdeki gemi tezgâhları/gemi yapım atölyeleri ve İskenderiye'deki tersanenin ıslahı ile başladığını syleyebiliriz. Araştırdığımız dönemde, birkaç iç denize ve gemilerin çalışmasına müsait nehirlere sahip olan İslâm âleminde, çok sayıda tersane yapıldığını görmekteyiz. Basra körfezinde Übülle, Sîrâf; İfrîkıyye'de Tunus, Trablûs; İspanya'da İşbiliyye, Dania; Fas'ta, Sûs; Sicilya'da Palermo, Messina; Suriye'de Akkâ, Sûr, Beyrût, Tarsûs; Mısır'da, Ravza, Fustât (Dârü's-Sınâati Mısr veya Amâir), Maks, İskenderiye ve Dimyât bunlardan bazılarıdır.

Bizans Donanması'nın Suriye sahil şehirlerine, 49/669 yılında vuku bulan saldırısından sonra Muâviye'nin, Ürdün bölgesinin/cündünün koruma ve savunması için Akkâ'daki tersaneleri yeniden inşa ve ıslah ettirdiğini; bu tersanelerde çalışacak usta, sanatkâr ve işçilerin ikametleri için sahil şeridi boyunca evler yaptırdı̆̆ını görmekteyiz.

Son Emevi halifesi Mervân b. Muhammed Saydâ limanının 132/750 senesinde yeniden ıslah ve onarımını yaptırmıștır. Saydâ deniz üssünün, Abbasi Halifesi Mütevekkil-Alellâh’ın da ilgi ve desteğini kazandığını ve Halife'nin, gemi yapımını emrettiği bütün sahil şehirleri içerisinde, burasının da yer aldığını görmekteyiz.

Tarsûs ünlü ve büyük bir şehirdir. Me'mûn onu yeniden imar etmiş; daha mükemmel ve medeni bir hale getirmiş ve şehrin etrafını iki sur ile çevirmiștir. Tarsûs ordugâhında; at, asker, mühimmat/savaş malzemesi (ikmal, levâzım), harp filosu, hayvan, silâh, mahsul, bolluk ve zenginlik başka yerde olduğundan çok daha fazla bir şekilde vardır. 


\section{Kaynakça}

Arîb b. Sa'd. Sılatü Târîhi't-Taberî. thk. M. J. De Goeje. Leiden: Brill, 1897.

Becker, C. H. "Cairo". Encyclopaedia of Islam. 1/815-826. Leiden: Brill, 1913.

Becker, C. H. "Dār al-Șinā'a". Encyclopaedia of Islam. 1/918. Leiden: Brill, 1913.

Bekrî, Abdullah b. Abdülazîz b. Muhammed Ebû Ubeyd el-. el-Mugrib fî zikri bilâdi Ifrikıyye ve'l-Magrib min Kitâbi'l-Mesalik ve'l-Memâlik. thk. M. G. De Slane. Paris-Cezayir: Typographie Adolphe Jourdan, 1911.

Belâzürî, Ebü'l-Abbas Ahmed b. Yahyâ b. Câbir el-. Fütûhü'l-büldân. Beyrut: Dârü'l-Kütübi'l-İlmiyye, 1978.

Belevî, Ebû Muhammed Abdullah b. Muhammed b. Umeyr el-. Siretü Ahmed b. Tolun. thk. Muhammed Kürd Ali. Dımașk: el-Mektebetü'l-Arabiyye, 1947.

Bell, H. I. "Translations of the Greek Aphrodito Papyri in the British Museum". Der Islam 3 (1910), 241-242.

Bell, H. I. "Translations of the Greek Aphrodito Papyri in the British Museum". Der Islam 4 (1913), 87-96.

Bell, H. I. "Translations of tho Greek Aphrodite Papyri in the British Museum". Der Islam 17 (1928), 4-8.

Bozkurt, Nebi. "Bahriye”. TDV İslâm Ansiklopedisi. 4/490-501. İstanbul, 2009.

Brooks, E. W. "The relations between the empire and Egypt from a new Arabic source". Byzantinische Zeitschrift 22/2 (1913), 381-391.

Buhl, F. “Akkā". Encyclopaedia of Islam. C. 1. Leiden: Brill, 1913.

Casanova, P. Description historique et topographique de l'Egypte. Kahire: Institut Français d'Archéologie Orientale, 1906.

Ebû Yûsuf, Ya'kub b. İbrâhim. Kitâbü'l-Harâc. thk. Muhibbüddin el-Hatib. Kahire: el-Matbaatü's-Selefiyye, 1936.

Ebü'l-Ferec Barhebraeus Yuhanna İbnü'l-İbrî, Abu'l-Farac Tarihi, çev. Ömer Rıza Doğrul (Ankara: Türk Tarih Kurumu, 1999)

Ebü'l-Fidâ, İmâdüddin el-Melikü'l-Müeyyed İsmail b. Ali. Takvîmu'l-Büldân. thk. M. G. De Slane. Paris, 1840.

Fehmi, Ali Muhammed. "el-Bayriyyetü'l-İslâmiyye fî şarkı'l-bahri'l-mütevassıt mine'l-karni's-sâbi' ile'l-âşiri'l-mîlâdî”. Târîhu'l-Bahriyyeti'l-Mısriyye. İskenderiye: Camiatü'l-İ̀skenderiye, 1973.

Halîfe b. Hayyât. Târîhu Halîfe b. Hayyât. Riyad, 1985.

Halîfe b. Hayyât. Târîhu Halîfe b. Hayyât. çev. Abdülhalik Bakır. Ankara: Bizim Büro Basımevi, 2001.

Hamidullah, Muhammed. Hz. Peygamber'in Savaşları. Ankara, ts.

Hamidullah, Muhammed. Íslam Peygamberi. çev. Salih Tuğ. 2 Cilt. İstanbul: İrfan Yayınevi, 1980.

Honigmann, E. “Sūr". Encyclopaedia of Islam. 4/557. Leiden: Brill, 1913.

Honigmann, E. "Sûr". Milli Eğitim Bakanlı̆̆ı İslam Ansiklopedisi. 11/42-46. İstanbul: Milli Eğitim Basımevi, 1979.

İbn Battuta, Ebû Abdullah Şemseddin Muhammed b. Abdullah. Tuhfetü'n-nezâir fî garâibi'l-emsâr ve acâibi'l-esfâr (Rıhletu İbn Batûta). thk. Defremeri-Sanguinetti. 3 Cilt. Paris: Imprimerie Nationale, 1893.

İbn Cübeyr, Muhammed b. Ahmed el-Endelüsî. Rihletü İbn Cübeyr. thk. M. J. De Goeje. Leiden: Brill, 1908. 
İbn Haldûn, Abdurrahmân b. Muhammed. Kitâbü'l-İber ve divanü'l-mübtede ve'l-haber fî eyyami'l-Arab ve'l-Acem ve'l-Berber ve men asarahum min zevi's-sultani'l-ekber. 7 Cilt. Beyrut, 1971.

İbn Havkal, Ebû'l-Kâsım Muhammed el-Bağdâdî. Kitâbu Sûreti'l-arz (el-Mesâlik ve'l-memâlik). thk. J. H. Kramers. Leiden: Brill, 1938.

İbn Miskeveyh, Ebû Ali Ahmed b. Muhammed b. Ya'kûb b. Miskeveyh. Tecâribü’l-ümem ve teâkiübu'l-himem. thk. Ferecullâh Zeki el-Kürdî. Mısır, ts.

İbn Rüste, Ebû Ali Ahmed b. Ömer. el-A'lâkü'n-nefîse. thk. M. J. De Goeje. Leiden: Brill, 1891.

İbn Tagrîberdî, Ebü'l-Mehâsin Cemâleddin Yûsuf b Tagriberdî. en-Nücûmü'z-zâhire fî mülûki Misr ve'l-Kahire. 17 Cilt. Kahire, 1972.

İbnü'l-Esîr, Ebü'l-Hasan İzzeddin Ali b. Muhammed b. Abdülkerim. el-Kâmil fi't-târîh. thk. Johannes Tornberg. 13 Cilt. Beyrut, 1965-1966.

İbnü'l-Fakîh, Ebû Bekr Ahmed b. Muhammed el-Hemedânî. Kitâbü'l-Büldân. thk. M. J. De Goeje. Leiden: Brill, 1885.

İbnü'l-İbrî, Ebü'l-Ferec Barhebraeus Yuhanna. Abu'l-Farac Tarihi. çev. Ömer Rıza Doğrul. 2 Cilt. Ankara: Türk Tarih Kurumu, 1999.

İdrîsî, Ebû Abdullah Muhammed eş-Şerîf b. Abdülazîz. Nüzhetü'l-müștâk fî ihtirâki'l-âfâk. thk. M. J. De Goeje. Leiden: Brill, 1866.

İstahrî, Ebû İshak İbrâhim b. Muhammed el-Fârisî el-Kerhî. Kitâbü'l-Mesâlik ve'l-Memâlik. thk. M. J. De Goeje. Leiden: Brill, 1927.

Jenkins, R. J. H. “The 'Flight' of Samonas". Speculum 23/2 (1948), 217-235. https:// doi.org/10.2307/2852953

Kazvînî, Zekeriyyâ b. Muhammed b. Mahmûd el-. Âsâru'l-bilâd ve ahbâru'l-ibâd. thk. F. Wüstenfeld. Göttingen: Dieterich, 1848.

Kindî, Ebû Ömer Muhammed b. Yusuf b. Yakub el-. Kitâbü'l-Vülât ve Kitâbü'l-Kudât. thk. Rhuvon Guest. Leiden: Brill, 1912.

Kudâme b. Ca'fer, Ebû'l-Ferec el-Kâtib el-Bağdâdî. "Nübez min Kitâbi'l-Harâc ve sınâ'ati'l-kitâbe li-Ebi'l-Ferec Kudâme b. Ca'fer el-Kâtib el-Bağdâdî”. Kitâbü'l-Mesâlik ve'l-Memâlik. thk. M. J. De Goeje. Leiden: Brill, 1889.

Le Strange, Guy. Palestin Under the Moslems. Boston: Houghton Mifflin Harcourt, 1890.

Makdisî, Şemsüddîn Muhammed b. Ahmed el-Beşşârî el-. Ahsenü't-tekâsîm fî ma'rifeti'l-ekâlîm. thk. M. J. De Goeje. Leiden: Brill, 1906.

Makrîzî, Takıyyüddin Ahmed b Ali b Abdülkadir el-. el-Mevâiz ve'l-i'tibâr fî zikri'l-hıtati ve'l-âsâr. 2 Cilt. Bulak: Dâru't-Tibâati'l-Misriyye, 1270.

Makrizî, Takıyyüddin Ahmed b Ali b Abdülkadir el-. Ittiâzü'l-hunefâ bi ahbâri'l-hulefâ. thk. Cemâleddin eş-Şeyyâl. Kahire: Dârü'l-Fikri'l-Arabi, 1948.

Mes'ûdî, Ebü'l-Hasan Ali b Hüseyin b Ali el- , et-Tenbîh ve'l-işrâf. Leiden: Brill, 1894.

Mes'ûdî, Ebü'l-Hasan Ali b Hüseyin b Ali el- , Mürûcü'z-zeheb. thk. C. Barbier de Meynard - Pavet de Courteille. 9 Cilt. Paris: Imprimerie Nationale, 1861-1877.

Nâsır-ı Hüsrev, Ebû Muîn Nâsır b. Hüsrev b. Hâris el-Mervezî. Sefernâme. thk. C. Schefer. Paris: Publications d'École de Langues Orientales Vivantes, 1881.

Runciman, Steven. The Emperor Romanus Lecapenus and His Reign: A Study of Tenth-Century Byzantium. Cambridge: Cambridge University Press, 1929.

Saîd b. Bitrîk. et-Tarihu'l-mecmû'ale't-tahkik ve't-tasdik, 1860.

Sâlih b. Yahyâ. Târîhu Beyrut. Beyrut, 1968. 
Sâlim, Abdülaziz. Dirâsetün fî Târîhi Medîneti Saydâ fi'l-Asri'l-İslâmî. Beyrut: Câmiatu Beyrut, 1970.

Sâlim, Abdülaziz. el-Bahriyyetü'l-Íslâmiyye fî Mısr ve'ş-Şâm mine'l-Fethi'l-Arabî hattâ'l-Asri'l-Eyyûbî. Beyrut: Dârü'n-Nahdati'l-Arabiyye, 1981.

Schlumberger, Gustave Léon. Un empereur byzantin au dixième siècle: Nicéphore Phocas. Paris: E. de Boccard, 1923.

Süyûtî, Ebü'l-Fazl Celâleddin Abdurrahman b. Ebî Bekr. Hüsnü'l-muhâdara fî târîhi Misr ve'l-Kahire. Kahire: Matbaatü İdâreti'l-Vatan, 1299.

Şidyak, Tannus b. Yusuf b. Mansur eş-. Ahbâru'l-a'yân fî Cebeli Lübnân. 2 Cilt. Beyrut: Metâbiu Semya, 1954.

Taberî, Muhammed b. Cerîr b. Yezîd et-. Târîhu'l-ümem ve'l-mülûk. 12 Cilt. Beyrut, ts.

Terzi, Mustafa Zeki. Hz. Peygamber ve Hulefâ-yi Râşidîn Döneminde Askeri Teşkilât. İstanbul: Siyer Yayınları, 2017.

Ya'kûbî, Ahmed b. İshâk b. Ca'fer el-. Kitâbü'l-Büldân. thk. M. J. De Goeje. Leiden: Brill, 1892.

Ya'kûbî, Ahmed b. İshâk b. Cacfer el-, Târîh, c.I-II. Beyrut 1960.

Yâkût el-Hamevî. Mu'cemü'l-büldân. 5 Cilt. Beyrut: Dâru Sâdır, 1955. 